\title{
Preconception health behaviors among women with planned pregnancies
}

\author{
Preparo pré-concepcional entre mulheres com gravidez planejada \\ Preparación preconcepción entre mujeres con embarazo planificado
}

\section{Natália de Castro Nascimento' ORCID: 0000-0003-2498-5281}

Ana Luiza Vilela Borges' ORCID: 0000-0002-2807-1762

\section{Elizabeth Fujimori' \\ ORCID: 0000-0002-7991-0503}

'Universidade de São Paulo. São Paulo, São Paulo, Brazil.

How to cite this article:

Nascimento NC, Borges ALV, Fujimori E. Preconception health behaviors among women with planned pregnancies.

Rev Bras Enferm. 2019;72(Suppl 3):17-24.

doi: http://dx.doi.org/10.1590/0034-7167-2017-0620

Corresponding Author:

Natália de Castro Nascimento

E-mail: natalia.castro.nascimento@usp.br

Submission: $10-22-2017$

\section{ABSTRACT}

Objective: To identify determinants of preconception preparation among women with planned pregnancies. Method: A cross-sectional study with a probabilistic sample of 264 women between 18 and 49 years of age who had or were undergoing planned pregnancies, and were users of two School Health Centers in the city of São Paulo. Analysis was conducted through univariate and multiple logistic regression of three variable blocks: 1) social and demographic characteristics; 2) sexual and reproductive characteristics; 3 ) preexisting health conditions. Results: Women with higher education, belonging to economic groups $\mathrm{A}$ and $B$, and older women with infertility were more likely to perform preconception training. Conclusion: Preconception care has a strong social determination, as women with more favorable social profiles are more likely to perform it. Experience with infertility is also instrumental in the likelihood of preconception care.

Descriptors: Preconception Care; Pregnancy; Women; Sexual and Reproductive Health; Maternal-Child Nursing.

\section{RESUMO}

Objetivo: Analisar os determinantes da realização do preparo pré-concepcional entre mulheres com gravidez planejada. Método: Estudo transversal com amostra probabilística de 264 mulheres de 18 a 49 anos de idade com gravidez atual ou anterior planejada, usuárias de dois Centros de Saúde Escola da cidade de São Paulo. Análise conduzida por meio de regressão logística univariada e múltipla em três blocos: 1) características sociais e demográficas; 2) características sexuais e reprodutivas; 3 ) condições de saúde preexistentes. Resultados: Mulheres de mais alta escolaridade, dos grupos econômicos A e B, mais velhas e com quadro de infertilidade tiveram maior chance de realizar o preparo pré-concepcional. Conclusão: $A$ realização do preparo pré-concepcional tem forte determinação social, pois mulheres com perfis sociais mais favoráveis apresentam maior chance de realizá-lo. Experiência de infertilidade também foi determinante para sua realização.

Descritores: Cuidado Pré-Concepcional; Gravidez; Mulheres; Saúde Sexual e Reprodutiva; Enfermagem Materno-Infantil.

\section{RESUMEN}

Objetivo: Analizar los determinantes de la realización de la preparación preconcepcional entre mujeres con embarazo planificado. Método: Estudio transversal con muestra probabilística de 264 mujeres de 18 a 49 años con embarazo planificado, usuarias de dos Centros de Salud Escuela de la ciudad de São Paulo. Análisis conducido por medio de regresión logística univariada y múltiple en tres bloques: 1) características sociales y demográficas; 2) características sexuales y reproductivas; 3 ) condiciones de salud preexistentes. Resultados: Las mujeres de más alta escolaridad, de los grupos económicos A y B, más viejas y con cuadro de infertilidad tuvieron mayor probabilidad de realizar la preparación preconcepcional. Conclusión: La realización de la preparación preconcepcional tiene fuerte determinación social, pues las mujeres con perfiles sociales más favorables presentan mayor probabilidad de realizarlo. La experiencia de infertilidad también fue determinante para su realización. Descriptors: Atención Preconceptiva; Embarazo; Mujeres; Salud Sexual y Reproductiva; Enfermería Maternoinfantil. 


\section{INTRODUCTION}

Preconception care is a set of health care practices adopted in the period prior to conception. It is important in improving reproductive health indicators, as it can prevent diseases during pregnancy, childbirth and the puerperium, which may reduce maternal and infant morbidity and mortality as well as the risk of genetic diseases ${ }^{(1)}$. These practices include the promotion of healthy eating and encouraging physical activity; health interventions related to the woman and couple's life and work conditions; guidance on the use of pharmaceutical preparations; the control and treatment of diseases such as diabetes, hypertension and syphilis; and, among couples with these specific needs, also genetic counseling and infertility treatment ${ }^{(1-2)}$.

Although studies show that pregnancy planning is fundamental for the couple to be able to carry out preconception care ${ }^{(3-5)}$ - since there seems to be no time or conditions for this practice in unplanned pregnancies ${ }^{(4)}$, - not every woman who want to become pregnant is actually prepared for the future pregnancy. This seems to occur because there are other elements associated with pregnancy planning, such as access to high quality health services, knowledge about what preconception care is and its importance ${ }^{(6)}$, and other individual and social aspects, such as high level of schooling, older age, paid jobs, stable relationship, preexisting disease, infertility and previous reproductive experience $^{(7-10)}$. At least this is what has been observed among women from high-income countries such as France, England and Italy, where preconception care is already in place and the proportion of planned pregnancies is relatively high ${ }^{(7-10)}$.

In Brazil, where the proportion of planned pregnancies is low ${ }^{(11-12)}$, little is known about the adoption of preconception care and how it is offered. A study conducted in the city of São Paulo showed that the main reason why women with planned pregnancies do not perform this type of take preconception measures is the lack of knowledge about it and about the services that offer $\mathrm{it}^{(13)}$. The scarce studies conducted in the country show, in fact, that preconception care is infrequent, reaching only $4.3 \%$ of the women, regardless of their reproductive intention ${ }^{(14)}, 19.8 \%$ of women with planned/ambivalent pregnancies, and $47 \%$ of women with planned pregnancies ${ }^{(5)}$.

Thus, it is necessary to investigate why women with planned pregnancies do not adopt any preconception care, considering that, theoretically, these women would have time to prepare for a healthy pregnancy. In a context of intense emphasis on the prenatal and puerperal period in the planning of health actions and organization of the country's primary health care services, pre-pregnancy actions with a view to improving maternal and child health become particularly relevant. Despite the fact that in Brazil there are few actions to promote pre-conceptional care in health services ${ }^{(15)}$, our hypothesis is that initiatives to adopt these measures among women with planned pregnancies have to be anchored in furthering women's social insertion and access to better-quality information and services. In this sense, women with a higher level of education that are from more privileged social groups are usually those who perform preconception care.

\section{OBJECTIVE}

To analyze the correlates of preconception measures adoption among women with planned pregnancies. Hopefully our results can support the implementation of preconception care, especially provided by nurses. A large study conducted in England, preconception care can be performed by nurses during family planning counseling, pap smear tests, postnatal care and to adolescents in health-related school activities ${ }^{(16)}$.

\section{METHOD}

\section{Ethical aspects}

This study was approved by the Research Ethics Committee of the School of Nursing of the University of São Paulo (EE/USP), Brazil. We also obtained written consent of the participants.

\section{Design, location of the study and study period}

This is a cross-sectional study conducted between April and June 2015 at two primary health care facilities (PHCF) that also work as undergraduate training scenario in a public university in the city of São Paulo, SP, Brazil. The PHCFs are linked to the University of São Paulo (USP) and, therefore, serve as a model unit, in the state of São Paulo, for the implementation of new programs able to guide the actions of the Ministry of Health and of the State and Municipal Health Secretariats. PHCSs can provide high quality preconception care.

\section{Inclusion and exclusion criteria}

The study was conducted among women between 18 and 49 years of age, who had a planned pregnancy in progress or had had a planned pregnancy in the five years prior to the survey. The sample size was calculated considering a $22.0 \%$ estimate of the studied phenomena ${ }^{(17)}$, a sample error of $5.0 \%$, and confidence interval of $95.0 \%$. The calculation showed that 264 women with planned pregnancies would have to be interviewed. Thus, the inclusion criteria was having a current or a previous planned pregnancy (prior five years). The choice of interviewing women who became pregnant during the five years prior to the survey is justified by the fact that national and international surveys use this period of time to evaluate pregnancy intention, like the National Survey of Demography and Child and Female Health - PNDS ${ }^{(18)}$.

To classify the pregnancy in relation to planning, the London Measure of Unplanned Pregnancy (LMUP), proposed by Geraldine Barrett (2002) ${ }^{(19)}$, was employed. This instrument has been validated for use in Brazil ${ }^{(20)}$ and in other contexts such as Malaysia and $\operatorname{Iran}^{(21-22)}$. The LMUP measures pregnancy planning and is comprised of six items. The pregnancy planning classification is obtained from the sum of each item's score, which can vary from 0 to 2 . The authors suggest that women with scores between 10 and 12 can be classified as having (or having had) a planned pregnancy. Women with score between 0 to 3 can be classified as undergoing unplanned pregnancy, and women with 4 to 9 are ambivalent regarding pregnancy planning ${ }^{(23)}$. 


\section{Study protocol}

Women between the ages of 18 and 49 who attended one of the PHCF every day of the week were invited to participate in the study. Information on consultations provided to pregnant women came from health professionals' schedules; women attending educational groups, immunization wards or any other PHCF activity were also considered. During the months of this study's data collection, there was a vaccination campaign against influenza, which facilitated the approach of a large number of women and favored interviews with those who attend the PHCF only occasionally. Among 482 women who were approached, 14 refused to participate in the survey, claiming to be busy or not willing. Two hundred and sixty-four (56.4\%) were classified as undergoing a planned pregnancy, 153 (32.7\%) as undergoing ambivalent pregnancies and 51 (10.9\%) as undergoing unplanned pregnancies; the latter two groups were excluded from this study.

Data collection was carried out in offices or in the waiting room. Face-to-face interviews had an average duration of 10 minutes and were conducted through a semi-structured instrument, with questions regarding social, demographic, reproductive, and health conditions.

To determine whether preconception care was performed, the following question was employed: When you planned to get pregnant in the current or last planned pregnancy, did you take any preparatory steps to improve your health or to organize for the arrival of the child? The answer to this question generated a dichotomous variable in which the women who answered positively in regards to any preparatory measure (one or more preparatory measures) were grouped in the "yes" category, while those who said they had not taken any preparatory measures for pregnancy were grouped in the "no" category.

Statistical analysis was performed in Stata 13.0, using preconception behavior as the (dichotomous) dependent variable. Independent variables were divided into three blocks. In Block 1 , which concerned social and demographic characteristics, the following aspects were considered: age (18-24 years, 25-29 years, 30-34 years, and 35 years or more), paid work (no/yes), partner (no/yes), socioeconomic status, according to Brazilian Association of Survey Companies (A/B and C/D groups) ${ }^{(24)}$, health insurance (no/yes), and schooling (elementary education, middle education, higher education or more). In Block 2, concerning sexual and reproductive history, age at the first sexual intercourse (11-19 years and 20 years or more), age at first pregnancy (14-19, 20-24, 25-29, and 30 years or more), number of pregnancies (one, two, three or more), number of children (none, one, two and three or more) and previous abortion (no/yes) were considered. In Block 3, which referred to pre-existing conditions, the following variables were considered: infertility (no/yes), preexisting diseases (no/yes), use of tobacco, alcohol and other drugs (no/ yes), history of genetic disease (no/yes), use of medications and treatment before pregnancy (no/yes), and consanguinity among partners (no/yes). These variables were considered according to the hypothesis that high schooling, older age, paid work jobs, stable relationship, preexisting disease, infertility and previous reproductive experience were associated with the adoption of preconception care behaviors. This hypothesis was based on the literature produced by studies conducted in high-income countries such as France, England and Italy ${ }^{(7,9-10)}$.

The variable 'presence of preexisting diseases' was selected based on the answers given to the question: Did you have any health problems before the current or the last planned pregnancy? Diseases indicated to be harmful in the preconception period were selected on the basis of healthcare manuals developed by the WHO and Brazilian Ministry of Health ${ }^{(1,25)}$ : diabetes, hypertension, epilepsy, anemia, thyroid diseases, asthma, mental disorders, sexually transmitted disease, infertility, gynecological diseases, autoimmune diseases, heart diseases, cancer, hepatitis, and nephropathies. The answers were grouped into the no/ yes categories. The variable infertility was constructed based on the answers given to the question "How long did it take you to become pregnant after you decided to?", categorized into "no" (less than two years) and "yes" (longer than two years), since WHO defines infertility as the inability of a sexually active couple using no contraceptive methods to conceive a pregnancy within two years ${ }^{(26)}$

\section{Analysis of results and statistics}

Results are described as absolute numbers, proportions, medians, minimum and maximum values, means and standard deviations. The independent variables associated with preconception care were analyzed using the chi-square test. Correlates of preconception care were verified through univariate and multiple logistic regression. The analysis was performed for the three blocks. In the multiple logistic regression analysis, we considered only the variables that were statistically significant on the univariate analysis $(p<0.05)$. Subsequently, the variables that remained statistically associated in the multiple analyzes of each block were analyzed simultaneously in the final multiple model. To identify association, a significance level of $5 \%$ was employed. The strength of association between the dependent and independent variables was assessed through odds ratio (OR), both in the univariate (OR) and multiple analysis (adjusted OR).

\section{RESULTS}

Table 1 shows preconception preparation according to the social and demographic characteristics of the 264 women with a current planned pregnancy or in the last 5 years. Women had a mean age of 32.1 years ( $S D=5.3$ years), most lived with a partner (96.2\%), worked (64.0\%) and were from social economic group $A$ and $B(68.6 \%)$. A little more than half had completed higher education (50.4\%) and had health insurance (50.4\%). In the social and demographic variables block, the following were statistically associated with preconception care: age $(p<0.001)$, paid work ( $p=0.034)$, socioeconomic status $(p<0.001)$, health insurance $(p<0.001)$, and schooling $(p<0.001)$.

Women had their first sexual intercourse, on average, at 18.0 years of age ( $S D=2.9$ years) and the first pregnancy at 26.4 years $(S D=6.7$ years). Among the characteristics of the reproductive profile, only the variables age at first sexual intercourse $(p=0.006)$ and age at first pregnancy $(p<0.001)$ were statistically significant with preconception care (Table 2 ). 
Table 1 - Preconception care according to women's social and demographic characteristics, São Paulo, São Paulo, Brazil, 2015

\begin{tabular}{|c|c|c|c|c|c|c|c|}
\hline Variable & \multicolumn{2}{|c|}{ Avg. } & \multicolumn{2}{|c|}{ SD } & Median & Min. & Max \\
\hline $\begin{array}{l}\text { Age (years) } \\
\text { Age of partner (years) }\end{array}$ & \multicolumn{2}{|c|}{32.1} & \multicolumn{2}{|c|}{$\begin{array}{l}5.3 \\
68\end{array}$} & $\begin{array}{l}32 \\
36\end{array}$ & $\begin{array}{l}20 \\
22\end{array}$ & $\begin{array}{l}43 \\
68\end{array}$ \\
\hline \multirow{3}{*}{ Variable } & \multicolumn{7}{|c|}{$\begin{array}{l}\text { Performed or performs } \\
\text { preconception care }\end{array}$} \\
\hline & \multicolumn{2}{|c|}{ No } & \multicolumn{2}{|c|}{ Yes } & \multirow[b]{2}{*}{$\mathbf{n}$} & \multirow[b]{2}{*}{$\%$} & \multirow{2}{*}{$\underset{\text { value* }}{p}$} \\
\hline & $\mathbf{n}$ & $\%$ & $\mathbf{n}$ & $\%$ & & & \\
\hline $\begin{array}{l}\text { Age } \\
18 \text { to } 24 \text { years } \\
25 \text { to } 29 \text { years } \\
30 \text { to } 34 \text { years } \\
35 \text { years old or more }\end{array}$ & $\begin{array}{l}19 \\
33 \\
26 \\
22\end{array}$ & $\begin{array}{l}19.0 \\
33.0 \\
26.0 \\
22.0\end{array}$ & $\begin{array}{l}7 \\
24 \\
60 \\
73\end{array}$ & $\begin{array}{c}4.3 \\
14.6 \\
36.6 \\
44.5\end{array}$ & $\begin{array}{l}26 \\
57 \\
86 \\
95\end{array}$ & $\begin{array}{c}9.8 \\
21.6 \\
32.6 \\
36.0\end{array}$ & $<0.001$ \\
\hline $\begin{array}{l}\text { Paid work } \\
\text { No } \\
\text { Yes }\end{array}$ & $\begin{array}{l}44 \\
56\end{array}$ & $\begin{array}{l}44.0 \\
56.0\end{array}$ & $\begin{array}{l}51 \\
113\end{array}$ & $\begin{array}{l}31.1 \\
68.9\end{array}$ & $\begin{array}{c}95 \\
169\end{array}$ & $\begin{array}{l}36.0 \\
64.0\end{array}$ & 0.034 \\
\hline $\begin{array}{l}\text { Lives with partner } \\
\text { No } \\
\text { Yes }\end{array}$ & $\begin{array}{c}6 \\
94\end{array}$ & $\begin{array}{l}6.0 \\
94.0\end{array}$ & $\begin{array}{c}4 \\
160\end{array}$ & $\begin{array}{c}2.4 \\
97.6\end{array}$ & $\begin{array}{c}10 \\
254\end{array}$ & $\begin{array}{c}3.8 \\
96.2\end{array}$ & 0.142 \\
\hline $\begin{array}{l}\text { Economic classification }{ }^{* *} \\
A \text { and } B \\
C \text { and } D^{* * *}\end{array}$ & $\begin{array}{l}49 \\
50\end{array}$ & $\begin{array}{l}49.5 \\
50.5\end{array}$ & $\begin{array}{c}132 \\
28\end{array}$ & $\begin{array}{l}82.5 \\
17.5\end{array}$ & $\begin{array}{c}181 \\
78\end{array}$ & $\begin{array}{l}69.2 \\
30.1\end{array}$ & $<0.001$ \\
\hline $\begin{array}{l}\text { Has a health insurance } \\
\text { No } \\
\text { Yes }\end{array}$ & $\begin{array}{l}69 \\
31\end{array}$ & $\begin{array}{l}69.0 \\
31.0\end{array}$ & $\begin{array}{c}62 \\
102\end{array}$ & $\begin{array}{l}37.8 \\
62.2\end{array}$ & $\begin{array}{l}131 \\
133\end{array}$ & $\begin{array}{l}49.6 \\
50.4\end{array}$ & $<0.001$ \\
\hline $\begin{array}{l}\text { Educational level } \\
\text { Elementary school } \\
\text { Middle school } \\
\text { Superior or more }\end{array}$ & $\begin{array}{l}19 \\
52 \\
29\end{array}$ & $\begin{array}{l}19.0 \\
52.0 \\
29.0\end{array}$ & $\begin{array}{c}10 \\
50 \\
104\end{array}$ & $\begin{array}{c}6.1 \\
30.5 \\
63.4\end{array}$ & $\begin{array}{c}29 \\
102 \\
133\end{array}$ & $\begin{array}{l}11.0 \\
38.6 \\
50.4\end{array}$ & $<0.001$ \\
\hline Total & 100 & 100 & 164 & 100 & 264 & 100 & \\
\hline
\end{tabular}

Note: *Chi-square test; ${ }^{* *}$ Variables missing (answers not a 100\% complete); ${ }^{* * *}$ The ' $E$ ' economic classification was not considered.

Table 2 - Preconception care according to the sexual and reproductive profile of women, São Paulo, São Paulo, Brazil, 2015

\begin{tabular}{|c|c|c|c|c|c|c|c|}
\hline Variable & Avg. & \multicolumn{2}{|c|}{ SD } & \multicolumn{2}{|c|}{ Median } & Min. & Máx. \\
\hline \multirow{2}{*}{$\begin{array}{l}\text { Age at } 1 \text { st intercourse (years) } \\
\text { Age at first pregnancy (years) }\end{array}$} & 18.0 & \multicolumn{2}{|c|}{2.9} & \multicolumn{2}{|c|}{18} & 11 & 30 \\
\hline & 26.4 & \multicolumn{2}{|c|}{6.7} & \multicolumn{2}{|c|}{26} & 14 & 42 \\
\hline \multirow{3}{*}{ Variable } & \multicolumn{7}{|c|}{$\begin{array}{l}\text { Performed or performs } \\
\text { preconception care }\end{array}$} \\
\hline & \multicolumn{2}{|c|}{ No } & \multicolumn{2}{|r|}{ Yes } & \multicolumn{2}{|c|}{ Total } & \multirow{2}{*}{$\begin{array}{c}p \\
\text { value* }\end{array}$} \\
\hline & $\mathbf{n}$ & $\%$ & $\mathbf{n}$ & $\%$ & $\mathbf{n}$ & $\%$ & \\
\hline \multicolumn{8}{|l|}{ Age at first intercourse (yea } \\
\hline $\begin{array}{l}11 \text { to } 19 \text { years } \\
20 \text { years old or more }\end{array}$ & $\begin{array}{l}87 \\
13\end{array}$ & $\begin{array}{l}87.0 \\
13.0\end{array}$ & $\begin{array}{l}118 \\
45\end{array}$ & $\begin{array}{l}72.4 \\
27.6\end{array}$ & $\begin{array}{c}205 \\
58\end{array}$ & $\begin{array}{l}77.9 \\
22.1\end{array}$ & 0.006 \\
\hline \multicolumn{8}{|l|}{ Age at first pregnancy (years) } \\
\hline 14 to 19 & 30 & 30.0 & 19 & 11.6 & 49 & & $<0.001$ \\
\hline 20 to 24 & 25 & 25.0 & 31 & 18.9 & 56 & 21.2 & \\
\hline 25 to 29 years & 29 & 29.0 & 33 & 20.1 & 62 & 23.5 & \\
\hline 30 years old or more & 16 & 16.0 & 81 & 49.4 & 97 & & \\
\hline \multicolumn{8}{|l|}{ Number of pregnancies } \\
\hline One & 38 & 38.0 & 70 & 42.7 & 108 & 40.9 & 0.295 \\
\hline Two & 46 & 46.0 & 60 & 36.6 & 106 & 40.2 & \\
\hline Three or more & 16 & 16.0 & 34 & 20.7 & 50 & 18.9 & \\
\hline \multicolumn{8}{|l|}{ Number of children** } \\
\hline None & 5 & 5.1 & 7 & 4.3 & 12 & 4.6 & 0.557 \\
\hline One & 45 & 45.4 & 89 & 54.3 & 134 & 50.9 & \\
\hline Two & 41 & 41.4 & 55 & 33.5 & 96 & 36.5 & \\
\hline Three or more & 8 & 8.1 & 13 & 7.9 & 21 & 8.0 & \\
\hline \multicolumn{8}{|l|}{ Previous abortion } \\
\hline No & 83 & 83.0 & 126 & 76.8 & 209 & 79.2 & 0.231 \\
\hline Yes & 17 & 17.0 & 28 & 23.2 & 55 & 20.8 & \\
\hline Total & 100 & 100 & 164 & 100 & 264 & 100 & \\
\hline
\end{tabular}

Note: *Chi-square test; **Variables missing (answers not a 100\% complete).
Table 3 - Preconception preparation according to women's preexisting conditions, São Paulo, São Paulo, Brazil, 2015

\begin{tabular}{|c|c|c|c|c|c|c|c|}
\hline \multirow{3}{*}{ Variable } & \multicolumn{7}{|c|}{$\begin{array}{l}\text { Performed or performs preconception } \\
\text { care }\end{array}$} \\
\hline & \multicolumn{2}{|c|}{ No } & \multicolumn{2}{|c|}{ Yes } & \multicolumn{2}{|c|}{ Total } & \multirow{2}{*}{$\underset{\text { value }}{p}$} \\
\hline & $n$ & $\%$ & $\mathbf{n}$ & $\%$ & $\mathbf{n}$ & $\%$ & \\
\hline \multicolumn{8}{|c|}{ Infertility ${ }^{* *}$} \\
\hline No & 90 & 91.8 & 132 & 81.9 & 222 & 85.7 & 0.028 \\
\hline Yes & 8 & 8.0 & 29 & 18.1 & 37 & 14.3 & \\
\hline \multicolumn{8}{|c|}{$\begin{array}{l}\text { Preexisting disease before } \\
\text { pregnancy }\end{array}$} \\
\hline No & 84 & 84.0 & 114 & 69.5 & 198 & 75.0 & 0.008 \\
\hline Yes & 16 & 16.0 & 50 & 30.5 & 66 & 25.0 & \\
\hline \multicolumn{8}{|c|}{$\begin{array}{l}\text { Use of tobacco, alcohol } \\
\text { and other drugs before } \\
\text { pregnancy }\end{array}$} \\
\hline No & 59 & 59.0 & 110 & 67.1 & 169 & 64.0 & 0.185 \\
\hline Yes & 41 & 41.0 & 54 & 32.9 & 95 & 36.0 & \\
\hline \multicolumn{8}{|c|}{$\begin{array}{l}\text { Outside of normal weight } \\
\text { before pregnancy** }\end{array}$} \\
\hline No & 56 & 56.0 & 90 & 54.9 & 146 & 55.3 & 0.409 \\
\hline Yes & 42 & 42.0 & 74 & 45.1 & 116 & 43.9 & \\
\hline \multicolumn{8}{|c|}{ History of genetic disease } \\
\hline No & 91 & 91.0 & 148 & 90.2 & 239 & 90.5 & 0.839 \\
\hline Yes & 9 & 9.0 & 16 & 9.8 & 25 & 9.5 & \\
\hline \multicolumn{8}{|c|}{$\begin{array}{l}\text { Use of medications and } \\
\text { treatment performed } \\
\text { before pregnancy }\end{array}$} \\
\hline No & 91 & 91.0 & 121 & 73.8 & 212 & 80.3 & 0.001 \\
\hline Yes & 9 & 9.0 & 43 & 26.2 & 52 & 19.7 & \\
\hline \multicolumn{8}{|c|}{$\begin{array}{l}\text { Consanguinity among } \\
\text { partners }\end{array}$} \\
\hline No & 97 & 97.0 & 160 & 97.6 & 257 & 97.3 & 0.783 \\
\hline Yes & 3 & 3.0 & 4 & 2.4 & 7 & 2.7 & \\
\hline Total & 100 & 100.0 & 164 & 100.0 & 264 & 100.0 & \\
\hline
\end{tabular}

Note: *Chi-square test; **Variables missing (answers not a 100\% complete).

As shown in Table 3 (women's preexisting conditions), 14.3\% of women reported infertility and almost half (43.9\%) were out of normal weight. In addition, more than one-third of women reported using tobacco, alcohol and other drugs (36.0\%). The bivariate analysis showed a statistically significant difference for preconception care in comparison to infertility $(p=0.028)$, preexisting diseases before pregnancy $(p=0.008)$, and use of medications and pre-pregnancy treatments $(p=0.001)$.

In the multiple logistic regression, results showed that, regarding social and demographic characteristics (Block 1), older women from socioeconomic groups $A$ and $B$ and women with higher educational levels were more likely to perform preconception care. Regarding sexual and reproductive characteristics (Block 2), women who had their first sexual intercourse at the age of 20 years or older had a higher odds of performing preconception care. Regarding the effect of preexisting health conditions (Block $3)$, women with preexisting diseases and infertility were more likely to perform preconception care (Table 4).

The final regression analysis of the statistically significant variables in the three blocks showed a significant effect of age, economic classification, schooling and infertility over preconception care. The presence of preexisting health conditions and age at first intercourse lost significance in the final multiple analysis. That is, older women, from higher socioeconomic status, highly educated and with fertility problems were more likely to perform preconception care (Table 5). 
Table 4 - Univariate and multiple logistic regression analysis of preconception care according to social, demographic, sexual and reproductive characteristics and preexisting conditions, São Paulo, São Paulo, Brazil, 2015

\begin{tabular}{|c|c|c|c|c|}
\hline \multirow{2}{*}{$\begin{array}{l}\text { Block I-social and } \\
\text { demographic variables }\end{array}$} & \multicolumn{2}{|c|}{ Univariate } & \multicolumn{2}{|c|}{ Multiple } \\
\hline & Gross OR & Cl $95 \%$ & Adj. OR & Cl 95\% \\
\hline \multicolumn{5}{|l|}{ Age (years) } \\
\hline 18 to 24 years & 1 & - & 1 & - \\
\hline 25 to 29 years & 2.0 & $0.71-5.43$ & 2.1 & $0.68-6.35$ \\
\hline 30 to 34 years & 6.3 & $2.34-16.70$ & 4.5 & $1.50-13.45$ \\
\hline$\geq 35$ years old & 9.0 & $3.34-24.21$ & 5.4 & $1.78-16.57$ \\
\hline \multicolumn{5}{|l|}{ Paid work } \\
\hline No & 1 & - & 1 & - \\
\hline Yes & 1.7 & $1.04-2.91$ & 1.3 & $0.7-2.34$ \\
\hline \multicolumn{5}{|l|}{ Economic classification } \\
\hline$A$ and $B$ & 1 & - & 1 & - \\
\hline C and D & 0.2 & $0.11-0.36$ & 0.5 & $0.22-0.94$ \\
\hline \multicolumn{5}{|l|}{ Educational level } \\
\hline Primary school & 1 & - & 1 & - \\
\hline Middle school & 1.8 & $0.77-4.31$ & 1.7 & $0.64-4.49$ \\
\hline Superior & 6.8 & $2.85-16.25$ & 3.1 & $1.04-8.96$ \\
\hline \multirow{2}{*}{$\begin{array}{l}\text { Block II - sexual and } \\
\text { reproductive variables }\end{array}$} & \multicolumn{2}{|c|}{ Univariate } & \multicolumn{2}{|c|}{ Multiple } \\
\hline & Gross OR & $\mathrm{Cl} 95 \%$ & Adj. OR & Cl 95\% \\
\hline \multicolumn{5}{|l|}{$\begin{array}{l}\text { Age at first sexual } \\
\text { intercourse }\end{array}$} \\
\hline $\begin{array}{l}\text { intercourse } \\
11 \text { to } 19 \text { years }\end{array}$ & 1 & - & - & - \\
\hline$\geq 20$ years old & 2.5 & $1.29-5.01$ & - & - \\
\hline \multicolumn{5}{|l|}{ Number of children } \\
\hline None & 1 & - & - & - \\
\hline One & 1.4 & $0.42-4.70$ & - & - \\
\hline Two & 1 & $0.28-3.23$ & - & - \\
\hline Three or more & 1.2 & $0.27-4.93$ & - & - \\
\hline \multirow{2}{*}{$\begin{array}{l}\text { Block III -preexisting } \\
\text { conditions }\end{array}$} & \multicolumn{2}{|c|}{ Univariate } & \multicolumn{2}{|c|}{ Multiple } \\
\hline & Gross OR & $\mathrm{Cl} 95 \%$ & Adj. OR & Cl 95\% \\
\hline \multicolumn{5}{|l|}{ Preexisting diseases } \\
\hline No & 1 & - & 1 & - \\
\hline Yes & 2.3 & $1.22-4.32$ & 2.4 & $1.17-4.34$ \\
\hline \multicolumn{5}{|l|}{$\begin{array}{l}\text { Use of tobacco, alcohol and } \\
\text { other drugs }\end{array}$} \\
\hline No & 1 & - & - & - \\
\hline Yes & 0.7 & $0.42-1.18$ & - & - \\
\hline \multicolumn{5}{|l|}{ Infertility } \\
\hline No & 1 & - & 1 & - \\
\hline Yes & 2.5 & $1.08-5.65$ & 2.4 & $1.02-5.51$ \\
\hline
\end{tabular}

Table 5 - Final multiple model of preconception care according to social, demographic, sexual and reproductive characteristics and pre-existing conditions, São Paulo, São Paulo, Brazil, 2017

\begin{tabular}{lccc}
\hline Variable & Category & \multicolumn{2}{c}{ Multiple } \\
& OR ajust & IC 95\% \\
\hline Age & 18 to 24 years & 1.0 & - \\
& 25 to 29 years & 2.4 & $0.73-8.19$ \\
& 30 to 34 years & 5.5 & $1.68-17.87$ \\
& $\geq 35$ years old & 5.7 & $1.71-18.69$ \\
Economic classification & A and B & 1.0 & - \\
& C and D & 0.4 & $0.20-0.94$ \\
Educational level & Primary school & 1.0 & - \\
& Middle school & 2.4 & $0.83-7.08$ \\
Preexisting diseases & Superior & 4.4 & $1.35-14.29$ \\
\multirow{2}{*}{ Infertility } & No & 1.0 & - \\
& Yes & 2.0 & $0.93-4.29$ \\
Age at first sexual intercourse & No & 1.0 & - \\
& Yes & 2.8 & $1.04-7.72$ \\
& 11 to 19 years & 1.0 & - \\
& $\geq 20$ years old & 1.5 & $0.71-3.33$ \\
\hline
\end{tabular}

\section{DISCUSSION}

The correlates of preconception behaviors among women with planned pregnancies are high schooling, belonging to economic classes A and B, experience of infertility, and older age.

Although pregnancy planning is an essential condition for preconception care ${ }^{(3-5)}$, this study identified other determinants and observed that the social context, above all, determines whether preconception care is performed. This finding differs from the international literature, which suggests a balance between biological, sexual and reproductive issues, in addition to social ones, in the determination of preconception care ${ }^{(7,9-10)}$. Thus, this study's results show that, even if women are able to plan their pregnancy, the adoption of healthy behaviors to prepare for pregnancy is subordinated to social inequality.

The association between older age and preconception care can be explained by the greater autonomy of women in cases in which pregnancy is postponed due to study and work or in which there is a delay in the timing of becoming pregnant due to infertility. The latter is also statistically associated with preconception care ${ }^{(10)}$. The literature ratifies these findings. Women who perform infertility treatments are more likely to perform preconception care ${ }^{(10)}$, since the difficulty of becoming pregnant generates concern and consequently leads them to seek specific care that includes preconception care.

It is also necessary to consider that there is a lack of this type of care in the Brazilian Unified Health System (SUS). A study indicated that there are few actions to promote preconception care in health services ${ }^{(15)}$, and that high-income women generally seek assistance in the private system. Another aspect with great relevance in women's decision to take preparation measures during the preconception period is their knowledge about importance of preconception health, which, in turn, is related to schooling. In fact, a study carried out in London, England, with women undergoing planned pregnancies showed that knowledge about preconception care favors it realization ${ }^{(27)}$.

Still concerning social context, unlike the English study ${ }^{(9)}$, this study shows that women's professional insertion is not directly associated with preconception care. This may be because, in our context, general work conditions and income are not as favorable. In other words, it seems that insertion in the labor market is not directly associated with high income.

Preexisting health conditions had no association with preconception care, although the literature shows that women with preexisting diseases are more likely to perform it ${ }^{(10)}$. The fact that no association between preconception care, preexisting health conditions and sexual and reproductive profile was found may indicate that previous use of health services did not provide women with conditions to adopt preconception behaviors. It is necessary to investigate if our primary health care services have been offering preconception care, but it seems that they have not. These are missed opportunities, since women who are counseled by health professionals before conception are more likely to adopt preconception care measures ${ }^{(7,9)}$. Health professionals should be expected to investigate the health conditions of women and/or couples in reproductive age and provide general and specific care for each case. In addition to assisting women who willingly 
seek health services specifically to receive preconception care, practitioners should take advantage of all other opportunities of contact with women of childbearing age to provide advice on this type of care ${ }^{(1-2)}$.

This recommendation is reinforced by current demographic and epidemiological trends, including increased obesity, diabetes, and pregnancies at older ages, which increase the importance of preconception care for overall health promotion. In this context, certain advantages of preconception care stand out: reduction of the incidence of neural tube defects through folic acid supplementation; reduction of preterm births, low birth weight and poor maternal, and neonatal outcomes while maintaining healthy body weight and nutrition; smoking cessation and reducing alcohol consumption prior to conception; reduction of infections through vaccination; and identification of occupational/environmental risks or use of medications that may be teratogenic ${ }^{(28)}$. This optimizes maternal and paternal health before conception, which consequently influences the future life course of the child, with significant health gains $\mathbf{s}^{(1,16)}$.

Because of the benefits of preconception care - such as reducing maternal and infant mortality ${ }^{(1)}$ - it should be incorporated into primary health care for all women of reproductive age, and primarily young women from low-income settings and chronic diseases. Nursing professionals are well-placed to incorporate preconception care into current healthcare practices ${ }^{(29)}$, thus contributing to effectively maximize gains in maternal and child health ${ }^{(1)}$.

\section{Limitations of this study}

The main limitation of this study is the differentiated socioeconomic profile of the women interviewed in comparison to the general population, which prevents the generalization of the findings. Compared to the general Brazilian population, the interviewed women are characterized by having greater schooling, belonging mainly to economic groups $A$ and $B$, and mostly living in stable unions ${ }^{(30)}$. The difference between the women in this study and the Brazilian women in general can be explained by the choice to conduct the study in PHCF located in neighborhoods with high Human Development Index (HDI)(31). However, considering that the differentiating characteristics are associated with preconception care, the point of this research was to investigate preconception care practices among women with greater possibility of performing this preparation. We suggest the development of studies that include women with different social profiles and from different contexts, so as to consider existing social inequalities in Brazil.

\section{Contributions to the area of nursing, health or public policy}

Considering that only half of Brazilian women plan their pregnancy, and given the importance of preconception care in maternal and child health, actions to promote preconception preparation in the agenda of public health policies and to provide conditions for women to plan their pregnancies are necessary. We reiterate the need for universal primary health care, that is, care for all women who aim to become pregnant. In addition, it is essential to provide conditions so that a greater number of women can plan their pregnancies and carry out preconception care. In this context, nursing has the ability to investigate the reproductive intent of men and women in all healthcare opportunities, and thus ensure preconception care.

\section{CONCLUSION}

Preconception preparation has a strong social determination, given that the women who performed it had the most favorable social profiles: high schooling and were from high socioeconomic status. The social determination supersedes particular life situations and health conditions, such as age at first intercourse, number of children, previous abortion, use of tobacco/alcohol/ other drugs, and preexisting conditions. In addition, experience of infertility and more advanced age are also determinants for performing preconception care.

Thus, given the importance of preconception care for maternal and child health, the Brazilian health system faces the challenge of providing it to all women, especially those who plan to become pregnant.

\section{REFERENCES}

1. World Health Organization (WHO). Meeting to develop a global consensus on preconception care to reduce maternal and childhood mortality and morbidity [Internet]. Geneva:WHO; 2012 [cited 2017 Jul 23]. Available from: http://apps.who.int/iris/ bitstream/10665/78067/1/9789241505000_eng.pdf

2. Ministério da Saúde (BR). Instituto Sírio-Libanês de Ensino e Pesquisa. Protocolos da Atenção Básica: Saúde das Mulheres [Internet]. Brasília: Ministério da Saúde; 2015 [cited 2017 Jul 23]. Available from: http://189.28.128.100/dab/docs/portaldab/publicacoes/protocolo_saude_mulher.pdf

3. Backhausen MG, Ekstrand M, Tydén T, Magnussen BK, Shawe J, Stern J, et al. Pregnancy planning and lifestyle prior to conception and during early pregnancy among Danish women. Eur J Contracept Reprod Health Care. 2014;19(1):57-65. doi: 10.3109/13625187.2013.851183

4. Dott M, Rasmussen SA, Hogue CJ, Reefhuis J. Association between pregnancy intention and reproductive-health related behaviors before and after pregnancy recognition, National Birth Defects Prevention Study, 1997-2002. Matern Child Health J. 2010;14(3):373-81. doi: 10.1007/s10995-009-0458-1

5. Borges ALV, Santos OA, Nascimento NC, Chofakian CBN, Gomes-Sponholz FA. Preconception health behaviors associated with pregnancy planning status among Brazilian women. Rev Esc Enferm USP. 2016;50(2):208-15. doi: 10.1590/S0080-623420160000200005

6. Mazza D, Chapman A. Improving the uptake of preconception care and periconceptional folate supplementation: what do women think? 
BMC Public Health. 2010;10:786. doi: 10.1186/1471-2458-10-786

7. Luton D, Forestier A, Courau S, Ceccaldi PF. Preconception care in France. Int J Gynaecol Obstet. 2014;125(2):144-5. doi: 10.1016/j. ijgo.2013.10.019

8. Stephenson J, Patel D, Barrett G, Howden B, Copas A, Ojukwu O et al. How do women prepare for pregnancy? Preconception experiences of women attending antenatal services and views of health professionals. PLoS One. 2014;9(7):e103085. doi: 10.1371/journal.pone.0103085

9. Tort J, Belong N, Prunet C, Khoshnood B, Blondel B. Maternal and health care determinants of preconceptional use of folic acid supplementation in France: results from the 2010 National Perinatal Survey. BJOG. 2013;120(13):1661-7. doi: 10.1111/1471-0528.12414

10. De Santis M, Quattrocchi T, Mappa I, Spagnuolo T, Licameli A, Chiaradia G, et al. Folic acid use in planned pregnancy: an Italian survey. Matern Child Health J. 2013;17(4):661-6. doi: 10.1007/s10995-012-1047-2

11. Borges ALV, Cavalhieri FB, Hoga LAK, Fujimori E, Barbosa LR. Pregnancy planning: prevalence and associated aspects. Rev Esc Enferm USP. 2011;45(spe. 2):1679-84. doi: 10.1590/S0080-62342011000800007

12. Leal MC, Gama SGN. Nascer no Brasil. Sumário executivo temático da pesquisa. Inquérito Nacional sobre Parto e Nascimento [Internet]. Rio de Janeiro: Fundação Oswaldo Cruz (Fiocruz); 2014 [cited 2017 Jun 23]. Available from: http://www.ensp.fiocruz.br/portal-ensp/informe/ site/arquivos/anexos/nascerweb.pdf

13. Nascimento NC, Araújo KS, Santos AO, Borges ALV. Preparo pré-concepcional: conhecimento e razões para a não realização entre mulheres usuárias do SUS. Bol Inst Saúde [Internet]. 2016 [cited 2017 Jun 23];17(2):96-104. Available from: http://www.saude.sp.gov.br/resources/ instituto-de-saude/homepage/pdfs/bis_saude_sexual.pdf

14. Mezzomo CLS, Garcias GL, Sclowitz ML, Sclowitz IT, Brum CB, Fontana T, et al. Prevenção de defeitos do tubo neural: prevalência do uso da suplementação de ácido fólico e fatores associados em gestantes na cidade de Pelotas, Rio Grande do Sul, Brasil. Cad Saúde Pública. 2007;23(11):2716-26. doi: 10.1590/S0102-311X2007001100019

15. Coelho EAC, Lucena MFG, Silva ATM. O planejamento familiar no Brasil no contexto das políticas públicas de saúde: determinantes históricos. Rev Esc Enferm USP. 2000;34(1):37-44. doi: 10.1590/S0080-62342000000100005

16. Ojukwu O, Patel D, Stephenson J, Howden B, Shawe J. General practitioners' knowledge, attitudes and views of providing preconception care: a qualitative investigation. Ups J Med Sci. 2016; 121(4):256-63. doi: 10.1080/03009734.2016.1215853

17. Cavalhieri FB. Adaptação cultural e validação para a língua portuguesa de um instrumento para mensuração de gravidez não planejada (London Measure of Unplanned Pregnancy) [Dissertação]. São Paulo: Universidade de São Paulo; 2011. doi: 10.11606/D.7.2011. tde-20062011-141727

18. Ministério da Saúde (BR). Política Nacional de Demografia e Saúde da Criança e da Mulher - PNDS 2006: dimensões do processo reprodutivo e da saúde da criança [Internet]. Brasília: Ministério da Saúde; 2009 [cited 2017 Jul 23]. Available from: http://bvsms.saude.gov. br/bvs/publicacoes/pnds_crianca_mulher.pdf

19. Barret G, Wellings K. What is a planned pregnancy? empirical data from a British Study. Soc Sci Med. 2002;55(4):545-57. doi: 10.1016/ S0277-9536(01)00187-3

20. Borges ALV, Barrett G, Santos OA, Nascimento NC, Cavalhieri FB, Fujimori E. Evaluation of the psychometric properties of the London Measure of Unplanned Pregnancy in Brazilian Portuguese. BMC Pregnancy Childbirth. 2016;16:244. doi: 10.1186/s12884-016-1037-2

21. Hall J, Barrett G, Mbwana N, Copas A, Malata A, Stephenson J. Understanding pregnancy planning in a low-income country setting: validation of the London measure of unplanned pregnancy in Malawi. BMC Pregnancy Childbirth. 2013;13:200. doi: 10.1186/1471-2393-13-200

22. Roshanaei S, Shaghaghi A, Jafarabadi MA, Kousha A. Measuring unintended pregnancies in postpartum Iranian women: validation of the London Measure of Unplanned Pregnancy. East Mediterr Health J [Internet]. 2015[cited 2017 Jul 23];21(8):572-8. Available from: http:// www.emro.who.int/emhj-volume-21-2015/volume-21-issue-8/measuring-unintended-pregnancies-in-postpartum-iranian-womenvalidation-of-the-london-measure-of-unplanned-pregnancy.html

23. Barrett G, Smith SC, Wellings K. Conceptualisation, development and evaluation of a measure of unplanned pregnancy. J Epidemiol Community Health. 2004;58(5):426-33. doi: 10.1136/jech.2003.014787

24. Associação Brasileira de Empresas de Pesquisa (ABEP). Critério de Classificação Econômica Brasil. [Internet]. São Paulo: ABEP; 2016 [cited 2017 Jun 18]. Available from: www.abep.org/Servicos/Download.aspx?id=07

25. Ministério da Saúde (BR). Secretaria de Atenção à saúde. Departamento de Atenção Básica. Atenção ao pré-natal de baixo risco [Internet]. Brasília: Ministério da Saúde; 2012 [cited 2017 Jun 20]. (Caderno de Atenção Básica n 32). Available from: http://bvsms.saude.gov.br/bvs/ publicacoes/cadernos_atencao_basica_32_prenatal.pdf

26. World Health Organization (WHO). Definitions and indicators in family planning maternal \& child health and reproductive health used in the WHO Regional Office for Europe [Internet]. Copenhagen: WHO Regional Office for Europe; 2001 [cited 2017 Jun 27]; Available from: http://apps.who.int/iris/bitstream/10665/108284/1/E68459.pdf

27. Barrett G, Shawe J, Howden B, Patel D, Ojukwu O, Pandya P, et al. Why do women invest in pre-pregnancy health and care? a qualitative investigation with women attending maternity services. BMC Pregnancy Childbirth. 2015;15:236. doi: 10.1186/s12884-015-0672-3

28. Gluckman PD, Hanson MA, Cooper C, Thornburg KL. Effect of in utero and early-life conditions on adult health and disease. N Engl J Med. 2008;359(1):61-73. doi: 10.1056/NEJMra0708473 
29. Coffey K, Shorten A. The challenge of preconception counseling: Using reproductive life planning in primary care. J Am Assoc Nurse Pract. 2014;26(5):255-62. doi: 10.1002/2327-6924.12054

30. Instituto Brasileiro de Geografia e Estatística (IBGE). Estatística de Gênero: uma análise dos resultados do Censo Demográfico 2010 [Internet]. Rio de Janeiro: IBGE; 2010 [cited 2017 Jun 19]. Available from: https://biblioteca.ibge.gov.br/visualizacao/livros/liv88941.pdf

31. Organização das Nações Unidas (ONU). Programa das Nações Unidas para o Desenvolvimento Humano (PNUD). Instituto de Pesquisas Econômicas Aplicadas (IPEA). Fundação João Pinheiro (FJP). O Índice de Desenvolvimento Humano Municipal Brasileiro. Série Atlas do Desenvolvimento Humano no Brasil 2013 [Internet]. Brasília: PNUD, IPEA, FJP; 2013 [cited 2017 Jun 19]; Available from: http://atlasbrasil.org. br/2013/data/rawData/publicacao_atlas_municipal_pt.pdf 